\title{
PENGEMBANGAN MEDIA VIDEO PEMBELAJARAN BERBASIS PENDEKATAN SCIENTIFIC PADA PELAJARAN BIOLOGI SMA
}

\author{
Eriko Silaban ${ }^{1}$, Efendi Napitupulu', Julaga Situmorang ${ }^{2}$ \\ ${ }^{1}$ SMA Methodist 12 Medan, Sumatera Utara \\ ${ }^{2}$ FT Universitas Negeri Medan, Sumatera Utara \\ erikosilaban@gmail.com
}

\begin{abstract}
Abstrak: Penelitian ini bertujuan untuk (1) menghasilkan media video pembelajaran berbasis pendekatan scientific pada pelajaran Biologi, (2) mengetahui keefektifan pengembangan media video pembelajaran berbasis pendekatan scientific, (3) mengetahui hasil belajar yang efektif terhadap video pembelajaran berbasis pendekatan scientific pada pelajaran Biologi. Jenis penelitian adalah penelitian pengembangan yang menggunakan model Borg and Gall yang dipadu dengan model desain pembelajaran dari Dick and Carey. Hasil penelitian menunjukkan: (1) uji ahli materi berada pada kualifikasi sangat baik (94,11\%), (2) uji ahli desain pembelajaran berada pada kualifikasi sangat baik (85,26\%), (3) uji ahli media pembelajaran berada pada kualifikasi sangat baik (86\%), (4) uji coba perorangan berada pada kualifikasi sangat baik (82,74\%), (5) uji coba kelompok kecil berada pada kualifikasi sangat baik (86,66\%), dan (6) uji coba pada lapangan terbatas berada pada kualifikasi sangat baik (86,78\%). Hasil pengujian hipotesis menunjukkan bahwa terdapat perbedaan yang signifikan antara hasil belajar peserta didik yang dibelajarkan menggunakan video dengan hasil belajar peserta didik yang dibelajarkan tanpa menggunakan video.
\end{abstract}

Kata Kunci: media video pembelajaran, pendekatan scientific, biologi

Abstract: This study aims to (1) produce a scientific approach based learning video media on Biology lessons, (2) determine the effectiveness of the development of scientific approach based learning video media, (3) find out effective learning outcomes for scientific approach based learning videos on Biology lessons. This type of research is development research that uses the Borg and Gall model combined with learning design models from Dick and Carey. The results showed: (1) the material expert test was in very good qualification (94.11\%), (2) the learning design expert test was in very good qualification (85.26\%), (3) the learning media expert test was at very good qualifications (86\%), (4) individual trials are in very good qualifications $(82.74 \%)$, (5) small group trials are in very good qualifications (86.66\%), and (6) test try on a limited field is very good qualification (86.78\%). The results of hypothesis testing indicate that there are significant differences between the learning outcomes of students who are taught to use video with the learning outcomes of students who are taught without using video.

Keywords: learning video media, scientific approach, biology

\section{PENDAHULUAN}

Di Indonesia, peningkatan mutu pendidikan adalah salah satu prioritas utama pogram pendidikan. Belajar merupakan satu kegiatan yang dilakukan secara sadar dan terencana yang mengarah kepada pencapaian tujuan dan hasil dari kegiatan belajar tersebut. Tercapainya tujuan belajar dalam bentuk pencapaian indikator merupakan satu gambaran keberhasilan peserta didik dan keberhasilan guru mentransfer pengetahuan kepada peserta didik. Oleh sebab itu, penetapan indikator keberhasilan belajar sangat diperlukan kejelasan terminologi yang digunakan dalam tujuan pembelajaran yang berfungsi untuk memberikan arah kepada penetapan pengalaman belajar dan menentukan perilaku yang akan dimiliki dan dikuasai peserta didik sebagai bukti telah melaksanakan proses kegiatan pembelajaran.

Menurut Hasratuddin (2002) bahwa salah satu kelemahan metode maupun model 
pembelajaran yang digunakan guru terlihat dari proses belajar mengajar yang dilaksanakan guru di kelas adalah guru lebih aktif dalam memberikan ilmu dan pengetahuan bagi peserta didik. Berarti dalam hal ini peserta didik bukan lagi sebagai subjek melainkan sebagai objek belajar. Dengan kata lain, pembelajaran berpusat pada guru (teaching centered). Salah satu faktor penting untuk mencapai tujuan itu adalah proses mengajar belajar (PBM) yang lebih menekankan kepada keterlibatan peserta didik secara optimal. Menurut Dahar (2001), sebab-sebab lulusan kurang bermutu atau belum memenuhi harapan adalah : (1) input yang kurang baik kualitasnya, (2) guru dan personal yang kurang tepat, (3) materi yang tidak atau kurang cocok, (4) metode mengajar dan system evaluasi yang kurang memadai, (5) kurangnya sarana penunjang, dan (6) sistem administrasi yang kurang tepat.

Berkaitan dengan praktik pembelajaran Biologi di sekolah, guru sangat berperan dalam menentukan berhasil tidaknya tujuan pembelajaran. Idealnya dalam merancang kegiatan pembelajaran, guru harus dapat melatih peserta didik untuk bertanya, mengamati, menyelidiki, membaca, mencari, dan menemukan jawaban atas pertanyaan baik yang diajukan oleh guru maupun yang mereka ajukan sendiri. Pengetahuan yang disampaikan kepada peserta didik bukan hanya dalam bentuk produk, tetapi juga dalam bentuk proses, artinya dalam proses mengajar, pengenalan, pemahaman, pelatihan metode, dan penalaran peserta didik, merupakan hal yang penting untuk diajarkan (Atmadi dkk, 2000).

Menurut Indrawati (2002) bahwa dalam upaya meningkatkan hasil pembelajaran Biologi yang optimal, para praktisi pendidikan Bilogi telah banyak memperkenalkan dan menerapkan berbagai strategi pembelajaran yang sesuai dengan karakteristik mata pelajaran Biologi. Dari beberapa strategi pembelajaran yang dikemukakan pakar pendidikan Biologi, dapat di lihat bahwa pemilihan dan penerapan strategi yang digunakan mengalami pergeseran dari yang mengutamakan pemberian informasi (pemberian konsep-konsep Biologi) menuju kepada strategi pembelajaran yang mengutamakan keterampilan-keterampilan berpikir yang digunakan untuk memperoleh dan menggunakan konsep-konsep Biologi.

Kurikulum 2013 menekankan penerapan pendekatan Scientific yang meliputi mengamati, menanya, mencoba, mengolah, menyajikan, menyimpulkan, dan mencipta untuk semua mata pelajaran (Sudarwan, 2013), dalam hal ini dalam rangka implementasi Kurikulum 2013 di lapangan guru salah satunya harus menggunakan pendekatan ilmiah (scientific), karena pendekatan lebih efektif hasilnya dibandingkan pendekatan tradisional dan merupakan tolak ukur dalam implementasi K13. Djamarah (2002) hasil belajar merupakan serangkaian kegiatan jiwa raga untuk memperoleh suatu perubahan tingkah laku sebagai hasil dari pengalaman individu berinteraksi dengan lingkungannya yang menyangkut kognitif, afektif dan psikomotorik. Adapun hasil belajar dalam bentuk afektif dan psikomotorik salah satunya adalah kemampuan keterampilan proses sains, hal ini disebabkan karena sains biologi memiliki komponen proses. Kemampuan keterampilan proses sains merupakan keseluruhan keterampilan yang terarah (baik kognitif dan psikomotor) yang dapat digunakan untuk menemukan suatu konsep, prinsip atau teori untuk mengembangkan konsep yang telah ada sebelumnya, atau untuk melakukan penyangkalan terhadap adanya penemuan.

Indrawati 2003 dalam (Trianto, 2008).

Untuk memperoleh hasil belajar dan keterampilan proses sains yang maksimal maka diperlukan analisa tentang penyebab hasil belajar dan keterampilan proses sains itu rendah, adapun beberapa hal yang menyebabkan terjadinya hasil belajar rendah adalah, (1) peserta didik kurang bersiap dalam menerima pelajaran, (2) kurangnya pengetahuan guru tentang pembelajaran yang inovatif, (3) guru masih mengajar dengan menggunakan pembelajaran konvensional.

Menurut Margaret (2001) yang menyebutkan bahwa (1) dalam pembelajaran peserta didik berusaha sendiri untuk menemukan pemecahan masalah, sehingga menghasilkan pengetahuan yang benar-benar bermakna, (2) Guru lebih mementingkan hasil dari pada proses pembelajaran. Akibatnya, belajar menjadi tidak bermakna, peserta didik akan kesulitan dalam memecahkan masalah yang lebih luas dan di kehidupan sehari-hari, 3) Metode pembelajaran yang diterapkan oleh guru masih didominasi oleh metode ceramah, latihan dan penugasan-penugasan mengerjakan soal-soal yang sifatnya pengetahuan saja.

Nurul (2013) menyebutkan pembelajaran berpendekatan scientific merupakan pembelajaran yang menggunakan 
pendekatan ilmiah dan inkuiri, dimana peserta didik berperan secara langsung baik secara individu maupun kelompok untuk menggali konsep dan prinsip selama kegiatan pembelajaran, sedangkan tugas guru adalah mengarahkan proses belajar yang dilakukan peserta didik dan memberikan koreksi terhadap konsep dan prinsip yang didapatkan peserta didik.

\section{Pendekatan Scientific pada Pembelajaran Biologi}

Sebelumnya telah disampaikan beberapa kegiatan yang dapat dilaksanakan sebagai penerjemahan dari masing-masing langkah dari pendekatan scientific, namun kegiatan-kegiatan yang dilakukan tentu akan berbeda sesuai dengan karakteristik mata pelajaran. Dalam kenyataanya karakter keilmuan dari setiap materi pelajaran tidak sama, sehingga pendekatan ilmiah dalam mata pelajaran tertentu tidak sama persis dengan mata pelajaran lainnya.

Dalam modul kurikulum 2013 tentang contoh penerapan pendekatan scientific dalam pembelajaran IPA (Kemendikbud, 2013) disampaikan bahwa pembelajaran IPA lebih menekankan pada penerapan keterampilan proses. Aspek-aspek pada pendekatan scientific terintegrasi pada pendekatan keterampilan proses dan metode ilmiah, sehingga penerapan kegiatan pendekatan scientific dalam IPA atau biologi juga diintegrasikan dengan keterampilan proses sains.

Keterampilan proses sains merupakan keterampilan-keterampilan yang dimiliki oleh para ilmuwan untuk memperoleh dan mengembangkan produk sains (Anitah, 2007). Keterampilan proses sains meliputi beberapa unsur keterampilan, yaitu mengamati, mengelompokkan/klasifikasi, menafsirkan, meramalkan, mengajukan pertanyaan, merumuskan hipotesis, merencanakan percobaan, menggunakan alat/bahan, menerapkan konsep, dan berkomunikasi. Unsur dalam keterampilan proses sains yang digunakan untuk menerjemahkan kegiatan belajar disesuaikan dengan langkah dalam pendekatan scientific, karena tidak semua unsur dalam keterampilan proses terdapat dalam langkah pendekatan scientific.

Menurut Hosnan (2014:35) pendekatan Scientific sangat relevan dengan tiga teori belajar, yaitu teori Bruner merupakan pembelajaran penemuan yang menekankan pengalaman-penglaman pembelajaran berpusat pada peserta didik menemukan ide-ide mereka sendiri dan menurunkan makna oleh mereka sendiri. Teori Piaget lebih menekankan pada adanya penilaian yang autentik dan belajar dengan menemukan sendiri pengetahuan peserta didik pada saat proses pembelajaran, dan Teori Vigotsky lebih menekankan pada interaksi sosial. Ketiga teori tersebut akan dijelaskan sebagai berikut.

\section{Hakikat Media Pembelajaran}

Kata media berasal dari bahasa latin dan merupakan bentuk jamak dari kata medium yang secara harfiah dapat diartikan sebagai perantara atau pengantar. Menurut Heinich, Molenda, dan Russel (1990) diungkapkan bahwa ; media is achannel of communication. Deriv ed from the latin word for "between", the term refers "to anything that carries information between a source and a receiver. Lesle J. Briggs (1979), menyatakan bahwa media pembelajaran sebagai "the physical means of conveying instructional content book, films, video, tapes, etc". Lebih jauh Briggs menyatakan media adalah "alat untuk memberi perangsang bagi peserta didik supaya terjadi proses belajar".

Rossi dan Breidle (1966), mengemukakan bahwa media pembelajaran adalah seluruh alat dan bahan yang dapat dipakai untuk tujuan pendidikan, seperti radio, televisi, buku, koran, majalah, dan sebagainya. Menurut Rossi, alat-alat semacam radio dan televisi kalau digunakan dan diprogram untuk pendidikan, maka merupakan media pembelajaran.

Namun demikian, media bukan hanya berupa alat atau bahan saja, akan tetapi hal-hal lain yang memungkinkan peserta didik dapat memperoleh pengetahuan. Gerlach dan Ely (1980) menyatakan: "A medium, conceived is any person, enable, skill and attitude". Menurut Gerlach secara umum media itu meliputi orang, bahan, peralatan atau kegiatan yang menciptakan kondisi yang memungkinkan peserta didik memperoleh pengetahuan, keterampilan, dan sikap. Jadi, dalam pengertian ini media bukan hanya alat perantara seperti tv, radio, slide, bahan cetakan, akan tetapi meliputi orang atau manusia sebagai sumber belajar atau juga berupa kegiatan semacam diskusi, seminar, karya wisata, simulasi dan lain sebagainya yang dikondisikan untuk menambah pengetahuan dan 
wawasan, mengubah sikap peserta didik atau untuk menambah keterampilan.

\section{Pengembangan Media Video Pembelajaran Berbasis Pendekatan Scientific Biologi}

Pengembangan dalam bahasa inggris disebut Development yang merupakan proses penerjemah spesifikasi rancangan menjadi bentuk fisik. Menurut Miarso (2004) mengemukakan bahwa pengembangan adalah cara yang dilakukan dengan menciptakan suatu model terbatas yang diawasi secara cermat terlebih berbagai komponen pengembangan dicobakan, dinilai dan disempurnakan. Sedangkan, menurut Rusijono dkk (2008) penilaian pengembangan adalah kegiatan yang menghasilkan produk yang dapat dipakai untuk memecahkan masalah aktual. Dalam hal ini kegiatan pengembangan ditekankan pada pemanfaatan teori, konsep, prinsip atau temuan penelitian untuk memecahkan masalah aktual. Dalam hal ini, kegiatan pengembangan ditekankan pada pemanfaatan teori, konsep, prinsip atau temuan penelitian untuk memecahkan masalah. Pengembangan (development) merupakan proses penterjemahan spesifikasi rancangan menjadi bentuk fisik. Seels \& Richey (1994) mendeskripsikan pengembangan sebagai: (a) pesan yang terkandung didalam isi, (b) strategi pembelajaran yang mengandung teori dan (c) perwujutan dari teknologi berupa perangkat keras dan lunak serta bahan-bahan media pembelajaran. Terkait dengan pengembangan ini, Miarso (2004) dilakukan dengan menciptakan sesuatu model terbatas yang secara cermat terlebih berbagai komponen pengembangan dicobakan, dinilai dan disempurnakan.

Dikaitkan dengan model pengembangan pembelajaran berarti merupakan rancangan atau tahap-tahap sebagai pedoman dalam pengembangan media yang akan dikembangkan dalam hal ini video pembelajaran. Model pengembangan pembelajaran berfungsi mengarahkan kita dalam mendesain pembelajaran yang dapat kita gunakan sebagai pedoman dalam pembelajaran guna mencapai pembelajaran efektif, efisien, berdaya guna, menarik dan humanis. Senada dengan hal tersebut model pembelajaran Dick \& Carey (2005) adalah salah satu contoh model pengembangan yang berorientasi pada hasil, karena penerapan konsep-konsep dan prinsip- prinsip perancangannya akan menghasilkan bahan belajar mandiri.

Dari tahapan pengembangan diatas, pengembangan yang akan dieksploitasikan disini berupa video pembelajaran dimana media sendiri memiliki arti yang beragam. Smaldino dkk (2003) video adalah "the storage of audio visuals and their display on television-type screen" yang diartikan penyimpanan atau perekaman gambar dan suara yang penayangannya pada layar televisi. Menurut Setyosari dkk (2005:117) video adalah sebagai media penyampian pesan, termasuk media audio-visual atau media pandang-dengar. Senada dengan pendapat Sanaky (2009) mengatakan bahwa media video adalah seperangkat alat yang dapat memproyeksikan gambar bergerak.

Kata media sendiri didefinisikan dengan multi makna, baik dilihat secara terbatas maupun secara luas. Media (bentuk jamak dari kata medium), merupakan kata yang berasal dari bahasa latin medius, yang secara harafiah berarti 'tengah', 'perantara' atau 'pengantar' (Arsyad, 2002).

Media dapat berupa sesuatu bahan (software) atau alat (hardware), sedangkan Gerlach \& Ely (dalam Arsyad, 2002), bahwa media jika dipahami secara garis besar adalah manusia, materi atau kejadian yang membangun kondisi, yang menyebabkan mahasiswa mampu memperoleh pengetahuan, ketrampilan, atau sikap. Pengertian ini sejalan dengan batasan yang disampaikan oleh Gagne (1985), yang menyatakan bahwa media merupakan berbagai jenis komponen dalam lingkungan siswa yang dapat merangsang untuk belajar. Menurut Daryanto (2010) media video adalah segala sesuatu yang bergerak memungkinkan sinyal audio dapat dikombinasikan dengan gambar secara sekuensial.

\section{Pembelajaran dengan Media Komputer}

Berbagai jenis aplikasi teknologi computer dalam pembelajaran pada umumnya dikenal dengan istilah Komputer Assited Instruction (CAI) atau dalam istilah yang sudah diterjemahkan sebagai "pembelajaran berbantuan komputer" (PBK). Menurut Chamber dan Sprecher (1983:354) menyatakan bahwa: "CIA refers to those applicaton of computer in instruction where a student engages in dialoque understanding or skill. CAI can profoundly after the manner in which a course is presented if sufficient high-quality". 
Dari beberapa pendapat diatas dapat disimpulkan bahwa CAI menunjukkan pada semua perangkat lunak pembelajaran yang diakses melalui komputer dimana mahasiswa dapat berinteraksi dengan komputer dan pembelajaran CAI sendiri memiliki tujuan pembelajaran berjenis driil and practice, tutorial and simulasi. Keberhasilan penggunaan komputer dalam pembelajaran tergantung berbagai faktor seperti proses kognitif dan motivasi belajar. Oleh karena itu prinsip-prinsip perancangan CAI diharapkan dapat melahirkan program yang menarik dan interaktif.

Prinsip-prinsip perancangan CAI menurut Arsyad (2003:165) antara lain: (1) belajar harus menyenangkan, (2) interaktiv, (3) kesempatan berlatih harus memotivasi, cocok dan tersedia feedback.

Masalah penelitian dirumuskan sebagai berikut: (1) Apakah video pembelajaran berbasis pendekatan scientific pada pelajaran biologi efektif dibelajarkan pada peserta didik?; (2) Apakah video pembelajaran berbasis pendekatan scientific pada pelajaran biologi layak digunakan untuk peserta didik?

\section{METODE}

Penelitian ini dilaksanakan kelas XI pada Semester genap. Dalam penelitian dan pengembangan ini model yang akan dikembangkan mengacu kepada Research and Development (R\&D) dari model Borg \& Gell (1983) yang memiliki tujuan untuk mengembangkan dan memvalidasai produk dengan perencanaan pembelajaran dalam pengembangan video pembelajaran Dick \& Carey (2009).

Adapun langkah-langkah dari tahapan pengembangan sebagai berikut:

1. Melakukan penelitian pendahuluan yang meliputi :

a. Identifikasi kebutuhan pembelajaran dan menentukan standar kompetensi pada pelajaran.

b. Melakukan analisis pembelajaran

c. Mengindentifikasi karakteristik dan perilaku awal peserta didik dan pengajar.

d. Menulis kompetensi dasar dan indikatornya

e. Menulis tes acuan patokan

f. Menyusun strategi pembelajaran yang diwujudkan dalam bentuk silabus dan satuan pembelajaran

g. Mengembangkan materi pembelajaran

h. Mendesain evaluasi formatif
2. Mendesain media video pembelajaran

a. Mengidentifikasi kembali materi dan dirangkum

b. Pembuatan naskah/storyboard

3. Pengumpulan bahan yang meliputi

a. Perekaman dan pengumpulan video

b. Meng-capture dan me-loging bahan hasil shooting pada program adobe premier ke dalam format avi

c. Editing (image, teks, sound effect, musik instrument, animation)

d. Render dengan menggunakan ekstensi mpeg (format VCD)

e. Mengembangkan dan membuat media video pembelajaran

f. Burning ke media VCD

4. Review dan uji coba produk

Tahap reviewer dan uji coba produk dilakukan kepada ahli materi, ahli media pembelajaran, ahli video dan desain grafis. Setelah melalui tahap revisi kemudian dilanjutkan kepada pengajar dengan tiga tahapan yaitu uji coba perorangan, uji coba kelompok kecil dan uji coba lapangan sehingga dihasilkan media video pembelajaran yang layak digunakan sesuai dengan karakteristik bidang studi dan pengajar sebagai pengguna. Melalui serangkaian uji coba ahli dan uji coba kepada pengajar akhirnya produk akhir media video pembelajaran dihasilkan dengan memasukkan saran dan revisi dari ahli isi/materi, media pembelajaran, ahli video dan desain grafis, serta peserta didik dan pengajar.

5. Uji keefektifan produk

Uji keefektifan produk dilakukan dengan cara melakukan analisa pembelajaran nantinya.

Prosedur pengembangan media video pembelajaran ini dilakukan dengan prosedur sebagai berikut :

1. Mengembangkan desain pembelajaran. Adapun langkah pengembangan desain pembelajarannya adalah sebagai berikut: (a) identifikasi kebutuhan instruksional dan menulis standar kompetensi mata pelajaran, (b) melakukan analisis pembelajaran, (c) mengidentifikasi karakteristik dan perilaku awal peserta didik, (d) menulis kompetensi dasar serta indikatornya, (e) menulis tes acuan patokan, (f) menyusun strategi pembelajaran, (g) mengembangkan bahan 
pembelajaran, (h) mendesain evaluasi formatif.

2. Pembuatan desain video pembelajaran yang akan dikembangkan dalam multimedia pembelajaran interktif, yang meliputi: (a) pembuatan flowchart, (b) pembuatan storyboard, (c) pembuatan naskah.

3. Pengumpulan bahan, yang meliputi: (a) pembuatan dan pengumpulan gambar (image), merekam suara, membuat animasi-animasi yang akan digunakan dalam materi maupun simulasi, (b) perekaman dan pengumpulan audio.

4. Mengembangkan bentuk awal produk dengan menggunakan program Aplikasi yang sesuai contoh: Macromedia Flash, Microsoft Powerpoint, Adove Premiere Elements 8, dll.

5. Melakukan validasi produk dari ahli media dan ahli materi

6. Melakukan revisi tahap pertama hasil dari validasi ahli media, dan ahli materi

7. Melakukan revisi produk tahap awal

8. Melakukan uji coba satu-satu dengan pengajar calon pengguna multimedia pembelajaran interaktif

9. Melakukan revisi tahap ke dua

10. Melakukan uji coba lapangan

11. Melakukan revisi akhir yang dikembangkan dalam produk video pembelajaran dalam bentuk multimedia pembelajaran interaktif.

\section{Teknik Pengumpulan Data}

Dalam penelitian ini digunakan tiga jenis teknik pengumpulan data, yaitu (1) tes untuk menjaring data hasil belajar denagn pendekatan scientific, (2) lembar pengamatan untuk menjaring hasil praktek Pendekatan Scientific, (3) lembar angket untuk memperoleh hasil data dari ahli materi, ahli desain pembelajaran, ahli media video dan grafis,pengajar dan peserta didik. Alat pengumpulan data yang digunakan untuk tes hasil belajar diberikan dalam bentuk pilihan berganda yang berjumlah 15 soal (multiple choice) dengan mengembangkan keterampilan peserta didik dalam menyelesaikan tes hasil belajar dan lembar pengamatan untuk menjaring hasil praktek pembelajaran berbasis pendekatan scientific ini diperoleh dari buku pegangan belajar bersumber dari Kementrian Pendidikan Nasional.
Oleh karena itu tidak dilakukan uji validitas dan uji keterandalan (realibilitas) karena instnrumen yang digunakan merupakan instrument baku yang telah dipergunakan.

\section{Teknik Analisis Data}

Analisis data dalam penelitian ini menggunakan analisis deskriptif kuantitatif, semua data yang terkumpul dianalisa dengan teknik statistik deskriptif yang secara kuantitatif dipisahkan menurut kategori untuk mempertajam penilaian dalam menarik kesimpulan. Data kualitatif yang berupa pernyataan sangat kurang baik, cukup, sedang dan sangat baik diubah menjadi data kualitatif dengan skala nilai 1 sampai 5. Hasilnya dibagi rata-rata dan digunakan untuk menilai kualitas media video pembelajaran. Kriteria media video akan dikonversikan menjadi nilai dengan skala lima menggunakan skala Likert yang dinamis secara deskriptif persentase dengan rumusan sebagai berikut Sugiyono (2007):

$$
\begin{aligned}
& \mathrm{X}=\frac{\text { Jumlah Skor yang diperoleh }}{\text { jumlah skor ideal seluruh item }} \times 100 \% \\
& \text { Keterangan: } \\
& \text { X = Skor Empiris }
\end{aligned}
$$

Dalam penelitian ini data yang diperoleh adalah hasil belajar pada biologi dari kelas. Teknik analisis data yang digunakan adalah teknik analisis isi media video pembelajaran, teknik analisis deskriptif dan teknik analisis uji t. teknik deskriptif adalah statistik yang digunakan untuk menganalisis data dengan cara menggambarkan data yang telah terkumpul sebagaimana adanya tanpa bermaksud membuat kesimpulan yang berlaku untuk umum atau generalisasi. Teknik inferensial adalah teknik statistik untuk menganalisis data sampel dan hasilnya diberlakukan untuk populasi.

\section{Efektifitas $=\frac{\text { JumlahSkor yang diperoleh }}{\text { Jumlah skor ideal seluruh item }} \times 100 \%$}

\section{HASIL PENELITIAN}

Penilaian yang dilakukan pada uji coba lapangan terbatas terhadap media video pembelajaran berbasis pendekatan scientific pada pelajaran biologi yang telah dikembangkan secara keseluruhan termasuk dalam kriteria "sangat baik" untuk seluruh indikator penilaian dengan persentase skor total $86.78 \%$. Berikut ini hasil uji coba lapangan terbatas terhadap media video pembelajaran 
JURNAL TEKNOLOGI INFORMASI \& KOMUNIKASI dalam PENDIDIKAN, Vol. 5 No. 1 Juni 2018, p-ISSN; 2355-4983, e-ISSN: 2407-7488

berbasis pendekatan scientific pada pelajaran video pembelajaran tersebut dapat dilihat pada biologi pada aspek kelayakan tampilan media

Tabel 1 sebagai berikut :

Tabel 1. Hasil Uji Coba Lapangan Terbatas terhadap Media Video Pembelajaran Berbasis Pendekatan Scientific

\begin{tabular}{|c|c|c|c|c|c|c|c|c|}
\hline \multirow{2}{*}{ No } & \multirow{2}{*}{ Indikator/Pertanyaan } & \multicolumn{4}{|c|}{ Skor Penilaian } & \multirow{2}{*}{$\begin{array}{l}\text { Jlh. } \\
\text { Skor }\end{array}$} & \multirow{2}{*}{$\begin{array}{l}\text { Rata- } \\
\text { rata }\end{array}$} & \multirow[b]{2}{*}{ Kriteria } \\
\hline & & 12 & 3 & 4 & 5 & & & \\
\hline & Tampilan & & & & & 685 & $91.33 \%$ & $\begin{array}{l}\text { Sangat } \\
\text { Baik }\end{array}$ \\
\hline 1 & $\begin{array}{l}\text { Teks atau tulisan pada video pembelajaran berbasis } \\
\text { pendekatan mudah dibaca }\end{array}$ & & 1 & 15 & 14 & 133 & $88.66 \%$ & $\begin{array}{l}\text { Sangat } \\
\text { Baik }\end{array}$ \\
\hline 2 & $\begin{array}{l}\text { Gambar yang disajikan pada video pembelajaran } \\
\text { berbasis pendekatan scientific }\end{array}$ & & & 12 & 18 & 138 & $92 \%$ & $\begin{array}{l}\text { Sangat } \\
\text { Baik } \\
\end{array}$ \\
\hline 3 & $\begin{array}{l}\text { Gambar yang disajikan sudah sesuai dengan video } \\
\text { pembelajaran berbasis pendekatan scientific }\end{array}$ & & & 12 & 18 & 138 & $92 \%$ & $\begin{array}{l}\text { Sangat } \\
\text { Baik } \\
\end{array}$ \\
\hline 4 & Gambar atau video yang disajikan menarik & & 2 & 10 & 18 & 136 & $90.66 \%$ & $\begin{array}{l}\text { Sangat } \\
\text { Baik } \\
\end{array}$ \\
\hline 5 & Gambar yang disajikan sesuai dengan materi & & & 10 & 20 & 140 & $93.33 \%$ & $\begin{array}{l}\text { Sangat } \\
\text { Baik } \\
\end{array}$ \\
\hline & Penyajian Materi & & & & & 970 & $92.38 \%$ & $\begin{array}{l}\text { Sangat } \\
\text { Baik }\end{array}$ \\
\hline 7 & $\begin{array}{l}\text { menjelaskan suatu konsep menggunakan ilustrasi } \\
\text { masalah yang berkaitan dengan topik struktur dan } \\
\text { fungsi sel-sel penyusun jaringan dalam Sistem } \\
\text { Pertahanan tubuh }\end{array}$ & & & 14 & 16 & 136 & $90.66 \%$ & $\begin{array}{l}\text { Sangat } \\
\text { Baik }\end{array}$ \\
\hline 8 & $\begin{array}{l}\text { menggunakan contoh-contoh yang berkaitan } \\
\text { dengan sistem pertahanan tubuh }\end{array}$ & & & 11 & 19 & 139 & $92.66 \%$ & $\begin{array}{l}\text { Sangat } \\
\text { Baik }\end{array}$ \\
\hline 9 & $\begin{array}{l}\text { Penyajian materi dalam video ini mendorong saya } \\
\text { untuk berdiskusi dan memecahkan masalah dengan } \\
\text { teman-teman yang lain pada pelajaran biologi topik } \\
\text { sistem pertahanan tubuh }\end{array}$ & & & 8 & 22 & 142 & $94.66 \%$ & $\begin{array}{l}\text { Sangat } \\
\text { Baik }\end{array}$ \\
\hline 10 & $\begin{array}{l}\text { Penyajian materi dalam video pembelajaran } \\
\text { berbasis pendekatan scientific pada pelajaran } \\
\text { biologi yang berkaitan dengan sistem pertahanan } \\
\text { tubuh dapat memecahkan masalah serta } \\
\text { menerapkannya }\end{array}$ & & & 13 & 17 & 137 & $91.33 \%$ & $\begin{array}{l}\text { Sangat } \\
\text { Baik }\end{array}$ \\
\hline 11 & $\begin{array}{l}\text { Saya dapat memahami materi struktur dan fungsi } \\
\text { sel-sel penyusun jaringan dalam sistem pertahanan } \\
\text { tubuh dengan mudah }\end{array}$ & & & 8 & 22 & 142 & $94.66 \%$ & $\begin{array}{l}\text { Sangat } \\
\text { Baik }\end{array}$ \\
\hline 12 & $\begin{array}{l}\text { Saya dapat mengikuti kegiatan belajar tahap demi } \\
\text { tahap dengan mudah }\end{array}$ & & & 12 & 18 & 138 & $92 \%$ & $\begin{array}{l}\text { Sangat } \\
\text { Baik }\end{array}$ \\
\hline 13 & $\begin{array}{l}\text { Saya dapat dengan mudah memahami kalimat yang } \\
\text { digunakan dalam video pembelajaran berbasis } \\
\text { pendekatan scientific pada pelajaran biologi ini }\end{array}$ & & & 14 & 16 & 136 & $90.66 \%$ & $\begin{array}{l}\text { Sangat } \\
\text { Baik }\end{array}$ \\
\hline & Manfaat & & & & & 558 & $93 \%$ & $\begin{array}{l}\text { Sangat } \\
\text { Baik }\end{array}$ \\
\hline 14 & $\begin{array}{l}\text { Saya dapat memahami materi sistem pertahanan } \\
\text { tubuh, antibodi dan antigen, imunisasi dengan } \\
\text { menggunakan video pembelajaran berbasis } \\
\text { pendekatan scientific dengan mudah }\end{array}$ & & & 9 & 21 & 141 & $94 \%$ & $\begin{array}{l}\text { Sangat } \\
\text { Baik }\end{array}$ \\
\hline 15 & $\begin{array}{l}\text { Saya merasa lebih mudah mempelajari sistem } \\
\text { pertahanan tubuh dengan pendekatan scientific } \\
\text { pada video ini }\end{array}$ & & 2 & 8 & 20 & 138 & $92 \%$ & $\begin{array}{l}\text { Sangat } \\
\text { Baik }\end{array}$ \\
\hline 16 & $\begin{array}{l}\text { Saya lebih tertarik dalam belajar menggunakan } \\
\text { pendekatan scientific menggunakan video ini }\end{array}$ & & & 7 & 23 & 143 & $95.33 \%$ & $\begin{array}{l}\text { Sangat } \\
\text { Baik } \\
\end{array}$ \\
\hline 17 & $\begin{array}{l}\text { Saya dapat memecahkan masalah dalam } \\
\text { pembelajaran sistem pertahanan tubuh } \\
\text { menggunakan video ini }\end{array}$ & & & 14 & 16 & 136 & $90.66 \%$ & $\begin{array}{l}\text { Sangat } \\
\text { Baik }\end{array}$ \\
\hline & Rata-rata & & & & & 2213 & $86.78 \%$ & $\begin{array}{l}\text { Sangat } \\
\text { Baik }\end{array}$ \\
\hline
\end{tabular}


Tabel 2. Persentase Rata-rata Hasil Penilaian Ahli Materi Terhadap Media Video Pembelajaran Berbasis Pendekatan Scientific

\begin{tabular}{llcl}
\hline No & $\begin{array}{l}\text { Indikator } \\
\text { Penilaian }\end{array}$ & $\begin{array}{l}\text { Persentase } \\
\text { Rata-rata }\end{array}$ & Kriteria \\
\hline 1 & $\begin{array}{l}\text { Aspek } \\
\text { Kelayakan } \\
\text { Isi }\end{array}$ & $96.66 \%$ & Sangat Baik \\
\hline 2 & $\begin{array}{l}\text { Aspek } \\
\text { Penyajian }\end{array}$ & $91.66 \%$ & Sangat Baik \\
\hline 3 & $\begin{array}{l}\text { Aspek } \\
\text { Kebahasaan }\end{array}$ & $93.33 \%$ & Sangat Baik \\
\hline 4 & $\begin{array}{l}\text { Aspek } \\
\text { Kegrafikan }\end{array}$ & $95 \%$ & Sangat Baik \\
\hline \multicolumn{2}{c}{ Rata-rata } & $\mathbf{9 4 . 1 1 \%}$ & Sangat Baik \\
\hline
\end{tabular}

\section{Analisis Data Penilaian Ahli Desain Pembelajaran}

Berdasarkan penialaian ahli desain pembelajaran terhadap media video pembelajaran berbasis pendekatan scientific pada pelajaran biologi yang dikembangkan telah memiliki kelayakan berdasarkan tiga aspek yaitu aspek kelayakan isi, aspek penyajian pembelajaran, aspek kegrafikan menunjukkan persentase rata-rata penilaian masing-masing $90 \%$ pada aspek kelayakan isi, $85.45 \%$ pada aspek penyajian pembelajaran, $80 \%$ pada aspek kegrafikan, secara keseluruhan termasuk kategori "sangat baik" dengan skor persentase rata-rata $85.26 \%$ yang berarti media video pembelajaran berbasis pendekatan scientific dapat memenuhi tuntutan kebutuhan pembelajaran. Adapun persentase rata-rata dari hasil penilaian ahli desain pembelajaran terhadap media video pembelajaran yang telah dikembangkan dapat dilihat pada Tabel 3 berikut ini.

Tabel 3. Persentase Rata-rata Hasil Penilaian Ahli Desain Pembelajaran terhadap Media Video Pembelajaran Berbasis Pendekatan Scientific

\begin{tabular}{llcc}
\hline No & Kategori & $\begin{array}{c}\text { Persentase } \\
\text { Rata-rata }\end{array}$ & Kriteria \\
\hline 1 & $\begin{array}{l}\text { Aspek } \\
\text { Kelayakan Isi }\end{array}$ & $90 \%$ & $\begin{array}{c}\text { Sangat } \\
\text { Baik }\end{array}$ \\
\hline 2 & $\begin{array}{l}\text { Penyajian } \\
\text { Pembelajaran }\end{array}$ & $85.45 \%$ & $\begin{array}{c}\text { Sangat } \\
\text { Baik }\end{array}$ \\
\hline 3 & Kegrafikan & $80 \%$ & Baik \\
\hline & Rata-rata & $\mathbf{8 5 . 2 6 \%}$ & $\begin{array}{c}\text { Sangat } \\
\text { Baik }\end{array}$ \\
\hline
\end{tabular}

Tabel 4. Persentase Rata-rata Hasil Penilaian Ahli Media Pembelajaran terhadap Media Video Pembelajaran Berbasis Pendekatan Scientific

\begin{tabular}{llcc}
\hline No & Kategori & $\begin{array}{c}\text { Persentase } \\
\text { Rata-rata }\end{array}$ & Kriteria \\
\hline 1 & $\begin{array}{l}\text { Aspek } \\
\text { Pemrograman }\end{array}$ & $87.50 \%$ & $\begin{array}{c}\text { Sangat } \\
\text { Baik }\end{array}$ \\
\hline 2 & $\begin{array}{l}\text { Kualitas } \\
\text { Teknis atau } \\
\text { Tampilan }\end{array}$ & $84.28 \%$ & $\begin{array}{c}\text { Sangat } \\
\text { Baik }\end{array}$ \\
\hline & Rata-rata & $\mathbf{8 6 \%}$ & $\begin{array}{c}\text { Sangat } \\
\text { Baik }\end{array}$ \\
\hline
\end{tabular}

\section{Analisis Data Hasil Uji Coba Perorangan}

Setelah melewati tahapan validasi para ahli, selanjutnya dilakukan uji coba perorangan untuk mengetahui persepsi peserta didik sebagai pengguna sebelum dilakukannya uji coba kelompok kecil terhadap media video pembelajaran berbasis pendekatan scientific yang dikembangkan. Hasil analisa data uji coba perorangan pada setiap aspek penilaian secara keseluruhan ditentukan oleh skor rata-rata pada kategorinya masing-masing. Hasil penilaian menunjukkan kriteria dengan "sangat baik" dengan persentase rata-rata $82.74 \%$. Penilaian ini terdiri dari beberapa kategori indikator penilaian yaitu aspek tampilan, penyajian materi pembelajaran, serta manfaat. Persentase persepsi peserta didik pada uji coba perorangan dapat dilihat pada Tabel 5 berikut ini.

Tabel 5. Persentase Perorangan Skor Uji Coba Perorangan Terhadap Media Video Pembelajaran Berbasis Pendekatan Scientific

\begin{tabular}{llcc}
\hline No & Kategori & $\begin{array}{c}\text { Persentase } \\
\text { Rata-rata }\end{array}$ & Kriteria \\
\hline 1 & $\begin{array}{l}\text { Aspek } \\
\text { Tampilan }\end{array}$ & $85.33 \%$ & $\begin{array}{c}\text { Sangat } \\
\text { Baik }\end{array}$ \\
\hline 2 & $\begin{array}{l}\text { Aspek } \\
\text { Penyajian }\end{array}$ & $85.57 \%$ & $\begin{array}{c}\text { Sangat } \\
\text { Baik }\end{array}$ \\
& $\begin{array}{l}\text { Materi } \\
\text { Pembelajaran }\end{array}$ & $90 \%$ & $\begin{array}{c}\text { Sangat } \\
\text { Baik }\end{array}$ \\
\hline 3 & Manfaat & $\begin{array}{c}\text { Sangat } \\
\text { Baik }\end{array}$ \\
\hline & Rata-rata & $\mathbf{8 2 . 7 4 \%}$ & \\
\hline
\end{tabular}




\section{Analisis Data Hasil Uji Kelompok Kecil}

Hasil analisis dapat pada uji coba kelompok kecil pada setiap aspek penilaian akan diuraikan pada tabel 6 sebagai berikut :

Tabel 6. Persentase Perolehan Skor Uji Coba Kelompok Kecil Terhadap Media Video Pembelajaran Berbasis Pendekatan Scientific

\begin{tabular}{llcc}
\hline No & Kategori & $\begin{array}{c}\text { Persentase } \\
\text { Rata-rata }\end{array}$ & Kriteria \\
\hline 1 & $\begin{array}{l}\text { Aspek } \\
\text { Tampilan }\end{array}$ & $92.44 \%$ & $\begin{array}{c}\text { Sangat } \\
\text { Baik }\end{array}$ \\
& $\begin{array}{l}\text { Video } \\
\text { Pembelajaran }\end{array}$ & & Sangat \\
Baik \\
\hline 2 & $\begin{array}{l}\text { Aspek } \\
\text { Penyajian } \\
\text { Materi } \\
\text { Pembelajaran }\end{array}$ & $91.11 \%$ & \\
\hline 3 & $\begin{array}{l}\text { Aspek } \\
\text { Manfaat } \\
\text { Video } \\
\text { Pembelajaran }\end{array}$ & $90.55 \%$ & $\begin{array}{c}\text { Sangat } \\
\text { Baik }\end{array}$ \\
\hline & Rata-rata & $\mathbf{8 6 . 6 6 \%}$ & $\begin{array}{c}\text { Sangat } \\
\text { Baik }\end{array}$ \\
\hline
\end{tabular}

\section{Analisis Data Hasil Uji Coba Lapangan Terbatas}

Uji coba lapangan terbatas dilakukan pada 30 orang peserta didik kelas XI guna mendapatkan informasi mengenai lanjutan keterpakaian media video pembelajaran untuk pemakai yang lebih banyak. Penilaian yang dilakukan pada uji coba ini mendapat kriteria dengan "sangat baik" dengan persentase ratarata $86.78 \%$. Untuk rincian penilaiannya dapat dilihat pada Tabel 7 berikut ini.

Tabel 7. Persentase Perolehan Skor Uji Coba Lapangan Terbatas Terhdap Media Video Pembelajaran Berbasis Pendekatan Scientific

\begin{tabular}{llcc}
\hline No & Kategori & $\begin{array}{c}\text { Persentase } \\
\text { Rata-rata }\end{array}$ & Kriteria \\
\hline 1 & $\begin{array}{l}\text { Aspek } \\
\text { Tampilan } \\
\text { Video } \\
\text { Pembelajaran }\end{array}$ & $91.33 \%$ & $\begin{array}{c}\text { Sangat } \\
\text { Baik }\end{array}$ \\
\hline 2 & $\begin{array}{l}\text { Aspek } \\
\text { Penyajian } \\
\text { Materi }\end{array}$ & $92.38 \%$ & $\begin{array}{c}\text { Sangat } \\
\text { Baik }\end{array}$ \\
\hline 3 & $\begin{array}{l}\text { Aspek } \\
\text { Manfaat }\end{array}$ & $93 \%$ & $\begin{array}{c}\text { Sangat } \\
\text { Baik }\end{array}$ \\
\hline & Rata-rata & $\mathbf{8 6 . 7 8 \%}$ & $\begin{array}{c}\text { Sangat } \\
\text { Baik }\end{array}$ \\
\hline
\end{tabular}

\section{Hasil Penelitian Uji Coba Efektifitas Produk} Deskripsi Data Penelitian

Data Hasil Belajar Peserta Didik Dengan

Menggunakan Video Pembelajaran Berbasis

Pendekatan Scientific

Berdasarkan data yang diperoleh dapat diketahui bahwa skor hasil belajar Biologi pada materi sistem pertahanan tubuh dengan menggunakan video pembelajaran berbasis pendekatan scientific diperoleh skor terendah 76 dan skor tertingi 99 , rata-rata skor 87,33 modus 89,62, median 88,3 dan simpangan baku 7,01 untuk melihat skor peserta didik digunakan kelas interval yaitu skor antara frekuensi absolute yaitu jumlah peserta didik yang memiliki skor hasil belajar, dan frekuensi realtif yaitu jumlah persen skor hasil belajar.

\section{Hasil Belajar Tanpa Menggunakan Media Video Pembelajaran Berbasis Pendekatan Scientific}

Berdasarkan data yang diperoleh dapat diketahui bahwa skor hasil belajar biologi pada topik sistem pertahanan tubuh tanpa menggunakan video pembelajaran berbasis pendekatan scientific diperoleh skor terendah 65 dan skor tertinggi 89, rata-rata skor 73,13 modus 76, median 74 dan simpangan baku 5,25. untuk melihat skor peserta didik digunakan kelas interval yaitu skor antar frekuensi absolute yaitu jumlah peserta didik yang memiliki skor hasil belajar, dan frekuensi relatif yaitu jumlah persen skor hasil belajar.

\section{Pengujian Persyaratan Analisis Data}

Uji persyaratan analisis data dilakukan untuk menentukan uji statistik parametrik hipotesis penelitian. Pengujian analisis data dilakukan dengan menguji normalitas data penelitian dengan uji Liliefors. Rangkuman uji normalitas data dengan uji Liliefors adalah sebagai berikut

Tabel 8. Rangkuman Uji Normalitas Data dengan Uji Liliefors

\begin{tabular}{cccccc}
\hline No. & Data & Kelas & L $_{\text {hitung }}$ & L $_{\text {tabel }}$ & $\begin{array}{c}\text { Kesim } \\
\text { pulan }\end{array}$ \\
\hline 1. & Postes & $\begin{array}{l}\text { Eksperi } \\
\text { men }\end{array}$ & 0,140 & 0,161 & Normal \\
\hline 2. & Postes & Kontrol & 0,144 & 0,161 & Normal \\
\hline
\end{tabular}

Sedangkan untuk menguji homogenitas data penelitian digunakan uji F. Rangkuman uji homogenitas data dengan uji Fisher sebagai berikut. 
Tabel 9. Rangkuman Uji Homogenitas Data Penelitian

\begin{tabular}{cccccc}
\hline No. & Data & Kelas & $\mathrm{F}_{\mathrm{h}}$ & $\mathrm{F}_{\mathrm{t}}$ & $\begin{array}{c}\text { Kesim } \\
\text { pulan }\end{array}$ \\
\hline 1. & Postes & Eksperimen & 1,19 & 1,88 & $\begin{array}{c}\text { Homo } \\
\text { gen }\end{array}$ \\
\hline 2. & Postes & Kontrol & & &
\end{tabular}

Uji t Postes

$\mathrm{H}_{0}: \mu_{1}=\mu_{2}$

$\mathrm{H}_{0}: \mu_{1}>\mu_{2}$

Keterangan :

$\mu_{1}$ : rata-rata hasil belajar speserta didik yang diajarkan menggunakan media video pembelajaran

$\mu_{2}$ : rata-rata hasil belajar peserta didik yang diajarkan tanpa menggunakan media video pembelajaran

$\mathrm{H}_{1}$ : tidak ada perbedaan hasil belajar Media Video Pembelajaran Berbasis Pendekatan Scientific yang diajarkan menggunakan media video pembelajaran lebih tinggi dari peserta didik yang diajar dengan pembelajaran tanpa menggunakan media video pembelajaran.

$\mathrm{H}_{2}$ : ada perbedaan hasil belajar biologi pada sistem pertahanan tubuh yang diajar menggunakan media video pembelajaran tanpa menggunakan media video pembelajaran.

Setelah dilakukan uji t postes menggunakan uji t. Hal ini dilakukan untuk mengetahui hipotesis dengan menggunakan uji t. Hal ini dilakukan untuk mengetahui apakah ada perbedaan hasil belajar peserta didik setelah dilakukan perlakuan yang berbeda.

Berdasarkan data pada Tabel 4.22 dan Tabel 4.23 di atas maka dapat disimpulkan bahwa data penelitian telah memenuhi persyaratan untuk dilakukan pengujian hipotesis.

\section{Pengujian Hipotesis}

Hipotesis yang diujikan pada penelitian ini adalah terdapat perbedaan yang signifikan antara hasil belajar peserta didik yang dibelajarkan menggunakan media video dan hasil belajar peserta didik yang tidak menggunakan media video. Pengujian hipotesis yang digunakan adalah uji t. Dari perhitunganperhitungan diperoleh output $t$ hitung sebesar 8,81 dan t tabel sebesar 1,83. Maka diperoleh bahwa $\mathrm{t}$ hitung $>\mathrm{t}$ tabel atau $8,81<1,83$ atau dengan kata lain Hi ditolak dan Ho diterima.
Berdasarkan data-data diatas maka disimpulkan bahwa hasil belajar peserta didik pada mata pelajaran biologi materi sistem pertahanan tubuh pada peserta didik yang diajarkan menggunakan media video pembelajaran berbasis pendekatan scientific teruji kebenaranya. Hal ini berarti hasil belajar yang menggunakan media video pembelajaran lebih tinggi dari peserta didik yang diajarkan tanpa pembelajaran menggunakan media video pembelajaran berbasis pendekatan scientific dengan efektifitas penggunaan media video pembelajaran berbasis pendekatan scientific sebesar $87,33 \%$. perhitungan selengkapnya pada lampiran.

Kefektifian media video pembelajaran berbasis pendekatan scientific pada pelajaran biologi dengan materi sistem pertahanan tubuh diperoleh dengan cara sebagai berikut : $\mathrm{X}=\frac{\text { Jumlah Skor yang diperoleh }}{\text { jumlah skor maksimal }} \times 100 \%$ $X=\frac{2620}{3000} \times 100 \%=87,33 \%$

Nilai keefektifan media video pembelajaran berbasis pendekatan scientific ini lebih tinggi dari nilai kefektifan pembelajaran tanpa media video pembelajaran yaitu sebesar $73,06 \%$ yang diuraikan sebagai berikut :

$\mathrm{X}=\frac{\text { Jumlah Skor yang diperoleh }}{\text { jumlah skor maksimal }} \times 100 \%$

$X=\frac{2192}{3000} \times 100 \%=73.06 \%$

Hal ini berarti hasil belajar peserta didik yang menggunakan media video pembelajaran berbasis scientific pada pelajaran biologi dengan materi sistem pertahanan tubuh lebih tinggi dari hasil belajar peserta didik yang diajar dengan pembelajaran tanpa menggunakan media video pembelajaran berbasis pendekatan scientific pada pelajaran biologi materi sistem pertahanan tubuh sebesar $87.33 \%$ perhitungan selengkapnya pada lampiran.

\section{PEMBAHASAN}

\section{Pembahasan Hasil Pengembangan Produk}

Pengembangan media video pembelajaran berbasis pendekatan scientific pada pelajaran biologi materi sistem pertahanan tubuh dilakukan berdasarkan tahapan sebagaimana yang terdapat dalam prosedur. Hasil pengembangan selanjutnya dilakukan uji kelayakan atau validasi oleh ahli yang telah ditentukan. Berdasarkan hasil validasi yang dilakukan, produk media video pembelajaran berbasis pendekatan scientific dinyatakan layak untuk diteruskan dalam uji coba lapangan. 
Media video Pembelajaran Berbasis Pendekatan Scientific yang dikembangkan telah memenuhi standar berdasarkan perancangan standar pengembangan media video pembelajaran dan standar materi pembelajaran.

Penelitian pengembangan produk yang dilakukan ini diarahkan untuk menghasilkan suatu produk berupa media video pembelajaran berbasis pendekatan scientific pada pelajaran biologi materi sistem pertahanan tubuh yang digunakan untuk meningkatkan proses pembelajaran maupun kompetensi peserta didik.

Aspek yang direvisi dan disempurnakan berdasarkan analisis data dan uji coba serta masukan dari ahli materi, ahli desain pembelajaran, ahli media video pembelajaran ini. Hal ini bertujuan untuk menggali beberapa aspek yang lazim dalam proses pengembangan suatu produk. Variable-variabel media video pembelajarn yang dinilai meliputi kelayakan isi, penyajian, kegrafikan, keaktifan, kebahasaan, pemograman, tampilan dan pemanfaatan.

Pada hasil angket yang disampaikan kepada ahli media video pembelajaran memberikan tanggapan $86 \%$ bahwa media video pembelajaran layak digunakan karena telah memenuhi prinsip-prinsip dan criteria pengembangan media video pembelajaran. Sementara itu, ahli desain pembelajaran memberikan tanggapan $85.26 \%$ bahwa media video pembelajaran berbasis pendekatan scientific pada pelajaran biologi materi sistem pertahanan tubuh layak digunakan karena telah didesain sedemikian rupa dan memenuhi standar desain pembelajaran. Ahli materi pembelajaran member tanggapan $94.11 \%$ bahwa media video pembelajaran berbasis pendekatan scientific layak digunakan karena telah memuat materi dan criteria penyampaian yang memenuhi syarat penyampaian pesan kepada peserta didik. Berdasarkan analisis hasil nilai rata-rata biologi yang diajarkan menggunakan media video pembelajaran berbasis pendekatan scientific sebesar $87.33 \%$, sedangkan hasil nilai rata-rata mata pelajaran biologi $73.06 \%$ ). Dengan melihat pedoman dan criteria penilaian menurut Sugiono (2010: 257) maka dapat disimpulkan data diatas membuktikan bahwa penggunaan media video pembelajaran berbasis pendekatan scientific pada pelajaran biologi materi sistem pertahanan tubuh lebih efektif dalam meningkatkan kompetensi dan pengetahuan peserta didik pada mata pelajaran biologi materi sistem pertahanan tubuh.

Beberapa kegunaan dan manfaat dalam penggunaan media video pembelajaran berbasis pendekatan scientific pada pelajaran biologi materi sistem pertahanan tubuh sebagai berikut : (1) materi dapat menyelesaikan permasalahan karena konsep yang direncanakan untuk mempermudah peserta didik dan sistematis, (2) media video pembelajaran berbasis pendekatan scientific memberi kesempatan kepada peserta didik untuk belajar sesuai dengan daya pikir masing-masing individu, (3) belajar lebih cepat dan menarik sehingga tidak menimbulkan kebosanan, (4) media video pembelajaran berbasis pendekatan scientific ini juga dapat digunakan sebagai alternative media video pembelajaran secara konvensional maupun individu, mengatasi jarak dan waktu, mampu menggambarkan kemudahan dengan menggunakan langkah-langkah scientific pada pembelajaran, dapat diulang-ulang bila perlu untuk menambah kejelasan, pesan yang disampaikannya cepat dan mudah diingat, dan mampu berperan sebagai media utama untuk memecahkan masalah yang akan disaksikan di dalam kelas.

\section{Pembahasan Hasil Penelitian Uji Coba Kelayakan Produk}

Berdasarkan hasil validasri yang dilakukan, produk media video pembelajaran berbasis pendekatan scientific pada pelajaran biologi materi sistem pertahanan tubuh dinyatakan layak untuk diteruskan dalam uji coba lapangan. Media video pembelajaran berbasis pendekatan scientific yang dikembangkan telah memenuhi standar berdasarkan perancangan standar pengembangan media video pembelajaran dan standar materi pembelajaran hal ini dapat terlihat pada Tabel 10 di bawah ini :

Tabel 10. Rangkuman Hasil Kelayakan Produk Berdasarkan Ahli Materi, Ahli Desain, Ahli Media Pembelajaran

\begin{tabular}{lll}
\hline $\begin{array}{l}\text { Ahli } \\
\text { Validasi }\end{array}$ & $\begin{array}{l}\text { Hasil } \\
\text { Persentase }\end{array}$ & $\begin{array}{l}\text { Layak / Tidak } \\
\text { Layak }\end{array}$ \\
\hline $\begin{array}{l}\text { Ahli Materi } \\
\text { Pembelajaran }\end{array}$ & $94.11 \%$ & $\begin{array}{l}\text { Layak } \\
\text { digunakan }\end{array}$ \\
\hline Ahli media & $86 \% \%$ & $\begin{array}{l}\text { Layak } \\
\text { digunakan }\end{array}$ \\
Pembelajaran & & $\begin{array}{l}\text { Layak } \\
\text { digunakan }\end{array}$ \\
\hline $\begin{array}{l}\text { Ahli desain } \\
\text { Pembelajaran }\end{array}$ & $85.26 \%$ & \\
\hline
\end{tabular}


Pada hasil angket yang disampaikan kepada ahli media video pembelajaran memberikan tanggapan $86 \% \%$ bahwa media video pembelajaran layak digunakan karena telah memenuhi prinsip-prinsip dan criteria pengembangan media video pembelajaran. Sementara itu, ahli desain pembelajaran memberikan tanggapan $85.26 \%$ bahwa media video pembelajaran berbasis pendekatan scientific layak digunakan karena telah didesain sedemikian rupa dan memenuhi standar desain pembelajaran. Ahli materi pembelajaran memberikan tanggapan $94.11 \%$ bahwa media video pembelajaran pembelajaran berbasis pendekatan scientific layak digunakan karena telah memuat materi dan criteria penyampaian yang memenuhi syarat penyampaian pesan kepada peserta didik.

\section{Pembahasan Hasil Penelitian Uji Keefektifian Produk}

Dari hasil pengolahan data penelitian yang dilakukan, terdapat rata-rata hasil bealajar biologi materi sistem pertahanan tubuh yang dibelajarkan menggunakan media video pembelajaran berbasis pendekatan scientific pada pelajaran biologi pada peserta didik yaitu sebesar $87.33 \%$. Sedangkah hasil belajar biologi materi sistem pertahanan tubuh diajarkan tanpa menggunakan media video pembelajaran sebesar $73.06 \%$. Dari data ini membuktikan bahwa media video pembelajaran berbasis pendekatan scientific pada pelajaran biologi materi sistem pertahanan tubuh ini layak dan efektif digunakan dalam meningkatkan kompetensi dan pengetahuan peserta didik.

Penggunaan media video pembelajaran berbasis pendekatan scientific memungkinkan peserta didik untuk lebih mudah memahami langkah-langkah scientific materi sistem pertahanan tubuh karena dari media video pembelajaran ini memungkinkan peserta didik untuk berinteraksi langsung, memiliki susunan tahapan pembelajarang yang lebih teratur dan lebih jelas, sehingga setiap peserta didik tidak kesulitan lagi dalam memecahkan masalah. Selain itu media video pembelajaran berbasis pendekatan scientific sangat praktis, karena media ini dapat dibawa peserta didik dan dipelajari di rumah.

\section{PENUTUP}

1. Pengembangan media video pembelajaran berbasis pendekatan scientific pada pelajaran biologi dibutuhkan oleh guru dan peserta didik dalam proses pembelajaran. Hasil validasi media video pembelajaran terhadap media video pembelajaran berbasis pendekatan scientific yang dikembangkan menunjukkan bahwa: (1) pada aspek kelayakan isi media video pembelajaran dinilai sangat baik dengan persentase sebesar $87,50 \%$, (2) pada aspek kegrafikan video pembelajaran dinilai sangat baik dengan persentase sebesar 84,28\%. Berdasarkan hasil validasi tersebut disimpulkan bahwa media video pembelajaran berbasis pendekatan scientific yang dikembangkan dalam criteria sangat baik (86\%), sehingga dapat diterima dan layak digunakan dalam proses pembelajaran.

2. Menurut tanggapan peserta didik pada uji coba perorangan dinyatakan bahwa media video pembelajaran berbasis pendekatan scientific yang dikembangkan dengan program Pinecel termasuk dalam kategori sangat baik dimana aspek kelayakan tampilan $85,33 \%$, aspek penyajian materi pembelajaran sebesar $88,57 \%$, dalam kategori sangat baik, dan aspek kemanfaatan media sebesar $90 \%$ dakam kategori sangat baik. Berdasarkan hasil uji coba perorangan tersebut disimpulkan bahwa media video pembelajaran yang dikembangkan termasuk dalam criteria sangat baik dengan skor ratarata persentase $82,74 \%$, sehingga layak digunakan dan dikembangkan dalam proses pembelajaran

3. Menurut tanggapan peserta didik pada uji coba kelompok kecil dinyatakan bahwa media video pembelajaran berbasis pendekatan scientific yang dikembangan dengan program Pinecel, xillsoft termasuk dalam kategori sangat baik dimana aspek kelayakan tampilan 92.44\%, aspek penyajian materi pembelajaran sebesar 91,11\% dalam kategori sangat baik dan aspek kemanfaatan media sebesar 90,55\% dalam kategori sangat baik. Berdasarkan hasil uji coba kelompok kecil tersebut disimpulkan bahwa media pembelajaran yang dikembangkan termasuk dalam criteria sangat baik $(86,66 \%)$.

4. Menurut tanggapan pada uji coba lapangan dinyatakan bahwa media video pembelajaran yang dikembangan dengan program Pinecel, xillsoft termasuk dalam kategori sangat baik dimana aspek kelayakan tampilan 91,33\%, aspek penyajian materi pembelajaran sebesar 
92,38\% dan aspek kemanfaatan media sebesar 93\%. Berdasarkan hasil uji coba lapangan terbatas tersebut disimpulkan bahwa media pembelajaran yang dikembangkan termasuk dalam criteria sangat baik $(86,78 \%)$.

5. Media video pembelajaran yang dikembangkan peneliti layak untuk digunakan sebagai media video pembelajaran untuk peserta didik, karena memiliki rata-rata $(87,33 \%)$ yang lebih tinggi dari pada nilai hasil belajar tanpa menggunakan video $(73,13)$.

6. Media video pembelajaran berbasis pendekatan scientific memiliki keefektifan sebesar $(87,33 \%)$ lebih tinggi dari keefektifan tanpa menggunakan media video pembelajaran berbasis pendekatan scientific $73,13 \%$.

\section{DAFTAR PUSTAKA}

Ansyar, Muhammad. 1988. Dasar-dasar Pengembangan, bandung: Alfabeta.

Arsyard, Azhar. 2011 . Media Pembelajaran. Jakarta : PT Raja Grafmdo Persada.

Bretz, Rudi. A. 1971. Taxonomy of Communication Media, Educational Technology Publications. Englewood, New Jersey.

Borg, W.R \& M.D. Gall. 1983. Educational Research: An Introduction, New York: Longman, Inc.

Chambers, J.A. dan Sprecher, J.W. 1983. Komputer Assisted Instruction It's Use in The Classroom. Inc, New Jersey, Prentice Hall.

Dick, W \& Carey, L. 2005. Systematic Design of Instructional (5 th ed). New York: Addison-Wesley Educational Publisher Educational Technology Publicational, Inc.

Dick, Walter, etc.2001. The Systematic Design of Instruction. Fifth Edition. Wesley Educational Publishers Inc..
Dahar, Ratna Wilis. 1989. Teori-Teori Belajar. Bandung: PT. Gelora Aksara Pratama

Djamarah \& Syaiful B. 2000. Guru dan Anak Didik Dalam Interaksi Edukatif. Jakarata: Rineka Cipta.

Gerlach Vernon. S, Elly Donald P. 1980. Teaching \& Media a System Approach. New Jersey: Prentice Hall.

Gagne, E.D. 1985. The Cognitive Psychology of School Learning. Boston, Toronto: Little, Brown and Company Light, $\mathrm{G}$.

Hosnan, M. 2014. Pendekatan Scientific dan Kontekstual dalam Pembelajaran abad 21 : Jakarta: Ghalia Indonesia

Hamalik, O. 2003. Kurikulum Dan Pembelajaran. Jakarta: Bumi Aksara.

Hosnan, M. 2014. Pendekatan Saintifik dan Kontekstual. Jakarta: Ghalia Indonesia.

Joyce, B., Weil, M., Calhoun, E. 2009. Models Of Teaching (Model-Model Pengajaran Edisi Kedelapan). Terjemahan oleh Achmad Fawaid dan Ateilla Mirza. 2009. Yogyakarta: Pustaka Pelajar

Miarso. 2011. Menyemai Benih Teknologi Pendidikan . Jakarta: Rencana Prenada Media grup.

Nurhadi, Wahyudi . 2003 . Media Pembelajaran . Jakarta : Gama Persada.

Rusijono, dkk. 2008. Penelitian Teknologi Pembelajaran, Surabaya: Unesa University Press.

Sanjaya, wing. 2010. Strategi Pembelajaran. Kencana Pernada Group.

Suparrman, Atwi, 2001, Desain Intruksional Modern. Jakarta :Penerbit Air Langga.

Seels, B.B. \& Richey, R.C. 1994. Instructional Technology: The Defenition and Domains of the Field. Washington DC: Association for Educatioanal Communications and Technology.

Smaldino, S. E dkk. 2008. Instructional Technology and Media for Learning. Jakarta: Kencana Prenada Media Group. 